\title{
SIEDEMNASTOWIECZNY „OGRÓD ZDROWIA”. PARNASSUS MEDICINALIS ILLUSTRATUS W TRADYCJI KOMPENDIÓW FARMACEUTYCZNYCH
}

Wśród starych druków Biblioteki Naukowej PAU i PAN w Krakowie znajduje się ofiarowany Akademii Umiejętności w 1884 r. przez Marię Jundziłł egzemplarz traktatu Parnassus medicinalis illustratus oder ein neues [...] gesehenes ThierKräuter- und Berg-Buch (sygn. PAU St. Dr. 13729) ${ }^{1}$ [il. 1]. Druk ten pochodzi z biblioteki jej ojca, litewskiego botanika, profesora Józefa Jundziłła (1794-1877)². Liczące ponad 900 stron kompendium stanowi XVII-wieczną adaptację gatunku „Gart der Gesundheit”. Tak zwane „ogrody zdrowia” cieszyły się olbrzymią popularnością w XV i pierwszej połowie XVI stulecia ${ }^{3}$. Były to kompendia wiedzy o leczniczych właściwościach roślin, zwierząt i minerałów. Tradycyjnie były one bogato ilustrowane, by ułatwić użytkownikom rozpoznanie i znalezienie poszczególnych substancji. Dodatkowo, drzeworyty Parnassusa stanowią interesujący przyczynek do badań nad mechanizmami upowszechniania ilustracji przyrodniczej w epoce nowożytnej. Zanim jednak zacznę rozważać specyfikę wydanego w latach 1662-1663 w Ulm Parnassusa, cofnę się o sto lat, by prześledzić ich genezę.

Śmierć Konrada Gesnera w 1565 r. była wielką stratą dla rozwoju XVI-wiecznej historii naturalnej. Powszechnie nazywany „ojcem zoologii” szwajcarski przyrodnik piastował urząd lekarza miejskiego Zurychu. Zmarł na dżumę, której epidemia

1 J. J. Becher, Parnassus medicinalis illustratus oder ein neues [...] Thier- Kräuter und Berg Buch, Ulm 1662-1663.

${ }^{2}$ B. Schnaydrowa, cytując ustalenia D. Rederowej i Z. Jabłońskiego podała, iż księgozbiór ten należał do ks. Stanisława Jundziłła (B. Schnaydrowa, Ofiarodawcy Akademii Umiejętności, „Rocznik Biblioteki Polskiej Akademii Nauk w Krakowie” R. 26 (1981), s. 15). Wg ustaleń P. Köhlera, księgozbiór Jundziłłów przekazany do bibliotek krakowskich w 1884 r. przez Marię Jundziłł należał do jej ojca Józefa, profesora Uniwersytetu Wileńskiego (P. Köhler, Biblioteka Naukowa Józefa Jundziłła (1794-1877), „Kwartalnik Historii Nauki i Techniki” R. 42, nr 3/4 (1997), s. 63-84; zob. też S. Tarnowski, Sprawozdanie z czynności naukowych i administracyjnych w roku 1884/1885, „Rocznik Zarządu Akademii Umiejętności w Krakowie” R. 1884, s. 82).

3 J. Rostafiński, Symbola ad historiam naturalem medii aevi, P. 1, Kraków 1900, s. 12-13. 
nawiedziła wówczas miasto. Gesner miał 49 lat i pozostawił po sobie bogaty dorobek naukowy. Największą sławę przyniosła mu wielotomowa encyklopedia historii naturalnej, w której zawarł informacje o właściwościach zwierząt czworonożnych, ptaków i ryb ${ }^{4}$. Aż do śmierci zbierał materiały i opracowywał kolejne jej części: poświęcone wężom - wydane już po jego śmierci ${ }^{5}$; owadom - zredagowane przez Thomasa Moffetta pod koniec lat 80. XVI w. i opublikowane dopiero w 1634 r. ${ }^{6}$, oraz pozostające w rękopisie do połowy XVIII w. kompendium botaniczne ${ }^{7}$.

Prócz tego, po Gesnerze pozostała pokaźna spuścizna naukowa. Uczony prowadził rozległe badania przyrodnicze, przy domu miał ogród botaniczny ${ }^{8}$, dysponował dużą biblioteką ${ }^{9}$ oraz kolekcją eksponatów i ilustracji ${ }^{10}$. Prowadził ożywioną korespondencję, która obejmowała wymianę nie tylko listów, ale też okazów i przedstawień ${ }^{11}$. Po śmierci Gesnera jego majątek został rozproszony. Duża część kolekcji rysunków zoologicznych trafiła do bazylejskiego lekarza i przyrodnika Felixa Plattera $^{12}$. Odziedziczone przez botanika Caspara Wolffa przedstawienia roślin, nabył w 1580 r. norymberski lekarz Joachim Camerarius Młodszy ${ }^{13}$. Kupione przez niego klocki drzeworytowe zostały przygotowane do zilustrowania opracowywanej przez Gesnera encyklopedii roślin. Camerarius wykorzystał gotowy zbiór w tłumaczonym przez siebie na niemiecki zielniku Pietra Andrei Mattiolego ${ }^{14}$. Wydana pod tytułem Kreutterbuch encyklopedia roślin leczniczych ukazała się w 1586 r. w oficynie Sigmunda Feyerabenda we Frankfurcie nad Menem.

Wykorzystał je on ponownie w edycji z 1590 r. Co działo się z nimi w późniejszych latach, nie sposób jednoznacznie ustalić. Jeżeli po śmierci Camerariusa pozostały w drukarni, ok. 1598-1600 r., spadkobiercy Feyerabenda odsprzedali je wraz z całym majątkiem oficyny augsburskiemu księgarzowi Eliasowi Willerowi, który przekazał go cesarskiemu lekarzowi Martinowi Rulandtowi ${ }^{15}$. Jeżeli nato-

${ }^{4} \mathrm{~K}$. Gesner, Historiae animalium libri, Zürich 1551-1558.

${ }^{5} \mathrm{~K}$. Gesner, Historiae animalium liber V., qui est de serpentium natura, Zürich 1587.

${ }^{6}$ T. Moffett, Insectorum sive minimorum animalium theatrum, London 1634.

${ }^{7}$ Ukazało się ono w opracowaniu C. Schmiedla pt. Conradi Gesneri Opera Botanica Per Duo Saecula Desiderata, Nürnberg 1754.

${ }^{8}$ D. Frietz, Konrad Gesner als Gärtner, Zürich 1948.

9 U. B. Leu, S. Weidmann, Conrad Gessner's private library, Leiden 2008.

${ }^{10} \mathrm{~F}$. Egmond, A collection within a collection. Rediscovered animal drawings from the collections of Conrad Gessner and Felix Platter collection, „Journal of the History of Collections” 24 (2012), s. $1-22$.

${ }^{11}$ C. Delisle, Accessing nature, circulating knowledge. Conrad Gesner's correspondence networks and his medical and naturalist practices, „History of Universities” 23 (2008), 2, s. 35-58.

12 F. Egmond, op. cit.

${ }^{13}$ Dzieje klocków ze zbiorów Gesnera przedstawił jako pierwszy R. Pulteney, Historical and biographical sketches of the progress of botany in England, P. 1, London 1790, s. 160-161. Jego relację powtarzano w wielu zbiorach anegdot publikowanych w I połowie XIX w. Zob. także H. Zoller, Conrad Gessner als Botaniker. „Gesnerus” 22 (1965), s. 216-227.

${ }_{14}$ P. A. Mattioli, Kreutterbuch, Frankfurt 1586.

15 J. Benzing, Feyerabend Sigismund [w:] Neue Deutsche Biographie, vol. 5 (1961), s. 119. 
miast, co wydaje mi się bardziej prawdopodobne, pozostały one w gestii rodziny Camerariusa, odziedziczył je jego syn i imiennik, Joachim Camerarius III, zmarły w 1642 r. Na poparcie tezy, że Frankfurt opuściły one dopiero w latach 40.-50. XVII w. może wskazywać fakt, że były w tym czasie kilkakrotnie wykorzystywane w różnych drukarniach frankfurckich do ilustracji kolejnych edycji Kreutterbuch oraz w innych tekstach botanicznych i farmaceutycznych. Jednym z wydawców, którzy mieli do nich dostęp, był Johannes Rhode. Uzupełnił je o przygotowane później drzeworyty znacznie gorszej jakości i wykorzystał w opublikowanym przez siebie w drukarni Nicolasa Hoffmanna 1609 r. zielniku Castora Durantesa w tłumaczeniu Petera Uffenbacha ${ }^{16}$. Ostatecznie, zapewne pod koniec lat 50. XVII w., klocki te kupił działający w Ulm drukarz Johann Görlin Starszy ${ }^{17}$. Niestety, ani o nim, ani o okolicznościach tego zakupu nie wiemy zbyt wiele. Ze wstępu do Parnassusa możemy jedynie wnioskować, że - z uwagi na swoje pochodzenie - zostały one za niebagatelną sumę pieniędzy sprzedane jako klocki ze zbiorów Joachima Camerariusa. Görlin nie zbagatelizował ich znaczenia i rychło znalazł dla nich zastosowanie. W 1662 r. zaczął wydawać Parnassum medicinalem illustratum, który został opatrzony licznymi ilustracjami odbitymi między innymi z tych, wykonanych sto lat wcześniej, klocków.

Tekst zilustrowanego ponad tysiącem drzeworytów i trzema tablicami miedziorytowymi kompendium przygotował Johann Joachim Becher (1635-1682/1685) ${ }^{18}$. Pochodzący ze Spiry uczony był lekarzem, mechanikiem i wynalazcą, zainteresowanym także chemią i alchemią. W 1661 r. obronił na uniwersytecie w Moguncji dysertację doktorską z medycyny, a dwa lata później objął stanowisko profesora tego uniwersytetu ${ }^{19}$. Pracował na dworach kilku arystokratów niemieckich, między innymi arcybiskupa Moguncji Johanna Philippa von Schönborn ${ }^{20}$, elektora Bawarii Ferdynanda Marii Wittelsbacha i grafa Hanau Fryderyka Kazimierza, a także cesarza Leopolda I w Wiedniu ${ }^{21}$. Wśród sobie współczesnych słynął jako alchemik, którego intrygowała tak praktyka, jak i teoria XVII-wiecznej chemii. Swoje ustalenia w tej

16 C. Durante, Hortulus sanitatis, das ist [...] Gährtin der Gesundheit, Frankfurt 1609.

17 Por. C. Reske Die Buchdrucker des 16. Und 17. Jahrhunderts im deutschen Sprachgebiet, Wiesbaden 2007, s. 260, gdzie wspomniany jest jego działający we Frankfurcie bratanek noszący to samo imię. Wśród drukarzy ulmskich wymieniona jest jedynie jego siostra, Anna, zamężna za Johannem Sebastianem Mederem i następnie Balthasarem Kühnem (zob. ibid., s. 934-936).

18 H. Hassinger, Becher, Johann Joachim [w:] Neue Deutsche Biographie, t. 1, Berlin 1953, s. $689-690$.

19 Interdyscyplinarność zainteresowań Bechera omawia M. Teich, Interdisciplinarity in Johann Joachim Becher's Thought [w:] Johann Joachim Becher (1632-1685), red. G.. Frühsorge i G. F. Strasser, Wiesbaden 1993, s. 23-40.

20 Moguncką działalność Bechera omawia H. Mathy, Wissenschaft ohne Grenzen. Johann Joachim Becher (1635-1685) als Mediziner und Chemiker in Mainz [w:] Moguntia medica. Das medizinische Mainz vom Mittelalter bis ins. 20. Jahrhudert, red. F. Dumont et al., Wiesbaden 2002, s. $47-53$.

${ }^{21}$ K. Ganzinger, Die Apotheke in J. J. Bechers Wiener Kunst- und Werkhaus, „Zur Geschichte der Pharmazie" 10 (1958), nr 1, s. 1-6. 
dziedzinie wykorzystywał w badaniach przyrodniczych i farmaceutycznych, a także do opracowania teorii ekonomii ${ }^{22}$. Becher był autorem licznych traktatów chemicznych i alchemicznych ${ }^{23}$. Nawiązujący do jego ustaleń w tych dziedzinach Parnassus stanowi w jego oeuvre dzieło wyjątkowe. Nie jest to dzieło stricte farmaceutyczne, ale - jak już wspomniałam - adaptacja kompendium z gatunku „Gart der Gesundheit”. Tego rodzaju teksty traktowały głównie o właściwościach medycznych roślin, zwierząt i minerałów, ale zawierały także informacje o metodach produkcji leków, a nierzadko również porady dotyczące zdrowego stylu życia.

Kompendium Bechera podzielone jest na cztery części. Zgodnie z tradycjami „Gärten der Gesundheit”, trzy pierwsze zawierają opisy trzech królestw natury zwierząt, roślin i „minerałów”, czyli substancji nieorganicznych. Wszystkie zebrane charakterystyki mają podobny schemat. Składają się z kilkuwersowego, wierszowanego opisu zwierzęcia, rośliny bądź związku chemicznego oraz omówienia jego właściwości medycznych.

Pierwsza księga, Zoologia ... nemlich das Thier-Buch traktuje o zwierzętach. Rozpoczyna ją szczegółowy opis ciała człowieka zilustrowany przedstawieniem Adama i Ewy w raju [il. 2]. Dalszą część Zoologii stanowią mniej rozbudowane charakterystyki 117 wybranych gatunków zwierząt czworonożnych, ptaków, ryb i stworzeń wodnych oraz owadów. Opisy czworonogów zilustrowano drzeworytowymi przedstawieniami [il. 3]. Natomiast rozdziałom poświęconym ptakom, zwierzętom wodnym i bezkręgowcom towarzyszą tablice miedziorytowe z kilkudziesięcioma zebranymi przedstawieniami opisywanych stworzeń [il. 4]. W przeciwieństwie do współczesnych Parnasussowi traktatów z zakresu historii naturalnej ${ }^{24}$, kompendium Bechera nie stanowi wyczerpującego źródła informacji o wszystkich gatunkach zwierząt. Wybrano je zgodnie z kryterium przydatności w pracy aptekarskiej. Opisane i zilustrowane zostały wszystkie gatunki zwierząt udomowionych, większość dzikich ssaków Europy oraz nieliczne gatunki zwierząt egzotycznych, które doceniano ze względu na ich użyteczność w medycynie. Wybór zwierząt pozaeuropejskich jest bardzo oszczędny nawet, jeśli wziąć pod uwagę, że zasadniczy korpus „Gärten der Gesundheit” opracowano jeszcze przed wyprawą Kolumba ${ }^{25}$. Są to wyłącznie stworzenia afrykańskie i azjatyckie: słoń, nosorożec, piżmowiec,

${ }^{22}$ Zob. np. R. von Erdberg-Krczenciewski, Johann Joachim Becher. Ein Beitrag zur Geschichte der Nationalökonomik, Jena 1896; P. H. Smith, Consumption and credit. The place of alchemy in Johann Joachim Becher's political economy [w:] Alchemy revisited. proceedings of the international conference on the history of alchemy at the University of Groningen, 17-19 April 1989, red. Z. Martels, Leiden, New York 1990, s. 215-221.

${ }^{23} \mathrm{~Np}$. J. J. Becher, Institutiones Chimicae Prodromae, Frankfurt 1664; Idem, Actorum Laboratorii Chymici Monacensis, Frankfurt 1669.

${ }^{24}$ Por. np. niewiele starsze Historiae naturalis libri Jana Jonstona wydawane we frankfurckiej oficynie Merianów w latach 1650-1653.

${ }^{25}$ Pierwsze drukowane wydanie ukazało się w Augsburgu w 1485 r. (J. de Cuba, Gart der Gesundheit, Augsburg 1485), zaś pierwsza edycja łacińska pochodzi z 1491 r. (Hortus sanitatis, Mainz 1491). 
cyweta, struś oraz skarabeusze, perłopławy i egzotyczne muszle. Becher uwzględnił też, jako jedyne zwierzę legendarne, jednorożca [il. 5].

Druga, najobszerniejsza księga Parnassusa, Phythologia ... nemlich das Kräuter-Buch traktuje o roślinach. W opracowanej na podstawie zielnika Mattiolego części Becher zebrał opisy wyglądu, właściwości i zasad uprawy ponad 800 gatunków roślin i grzybów. Kompendium koncentruje się na charakterystykach uwzględnianych w dawnych zielnikach i popularyzowanych przez nowożytną medycynę. W księdze zamieszczono znacznie więcej ilustracji niż w poprzedniej części. Praktycznie wszystkie charakterystyki są opatrzone drzeworytowymi przedstawieniami botanicznymi [il. 6].

Trzecia księga, Mineralogia ... nemlich das Berg-Buch opisuje właściwości „minerałów”. Zebrano w niej opisy piętnastu różnych substancji nieorganicznych niezbędnych w pracy tak chemika, jak i aptekarza. Są to opracowane na podstawie teorii Paracelsusa charakterystyki metali oraz różnego rodzaju związków chemicznych, pochodnych siarki, azotu i wapnia. Opisy te zawierają suche wyliczenie właściwości fizycznych i chemicznych, możliwości zastosowania tych substancji w farmacji oraz ich związki z ciałami niebieskimi stanowiące podstawę dla studiów astrologicznych i alchemicznych. Charakterystykom wielu ,minerałów” towarzyszą drzeworyty z alegorycznymi przedstawieniami związanych z nimi ciał niebieskich trzymającymi symbole alchemiczne [il. 7].

Czwarta księga traktatu, Schola salernitana, to pierwsze tłumaczenie na język niemiecki Regiminis sanitatis salernitanum, poradnika zdrowego życia spisanego rzekomo w XII bądź XIII w. przez Jana z Mediolanu w Szkole medycznej w Salerno i w XIV w. uzupełnionego komentarzem przypisywanym Arnaldowi de Villanova. Poszczególne rozdziały tej księgi opisują prawidłowy rozkład dnia, wskazówki dietetyczne, wpływ pożywienia na zdrowie i samopoczucie człowieka, cechy różnych typów temperamentu oraz niektórych chorób, które uznawano za efekt nierównowagi humorów.

Ostatnią, dołączoną do czwartej księgi część kompendium stanowią przydatki, zawierające praktyczne rady dla aptekarza i alchemika. Prócz stricte użytkowych komentarzy do poszczególnych ksiąg traktatu, znajduje się tam również poradnik wykorzystania narzędzi do destylacji, ilustrowany przedstawieniami wczesnonowożytnego sprzętu laboratoryjnego [il. 8].

Parnassus był jedną z pierwszych publikacji Bechera. Wydany został wkrótce po uzyskaniu przez niego doktoratu. Przed przybyciem do stolicy Nadrenii, Becher był raczej samoukiem i wędrownym wynalazcą, a uznanie zaczął zdobywać dzięki swojemu pierwszemu patronowi, którym był arcybiskup Moguncji Johann Philipp von Schönborn ${ }^{26}$. To właśnie jemu, zatrudniony jako medicus dworu arcybiskupiego, Becher dedykował Parnassum medicinalem illustratum.

Dedykacja przedstawia skrótowo główne tezy dzieła oraz okoliczności, w jakich doszło do jego napisania. Gdy Johann Görlin nabył, nota bene ,nie bez dużych

26 Zob. P. H. Smith, The business of alchemy, Princeton 1994, s. 63. 
kosztów" 27 , klocki Camerariusa, uznał je za niezwykle cenne i warte ponownego wydania. Dlatego zamówił u Bechera dostosowany do nich zaktualizowany tekst zielnika dla farmaceutów. Becher, starając się opracować możliwie kompletne dzieło, nie tylko sparafrazował przetłumaczone przez Camerariusa charakterystyki roślin, ale dodał też inne teksty, opisujące właściwości zwierząt i minerałów oraz porady dotyczące zdrowego życia i przygotowywania leków. Nowe księgi wymagały uzupełnienia o nowe ilustracje, które wykonano już na miejscu, w Ulm.

Parnassus medicinalis illustratus jest dziełem przestarzałym. Gatunek „Gärten der Gesundheit" jest jeszcze średniowieczny. Tekst, w dużym stopniu sparafrazowany w drugiej połowie XVII w., czerpie z dzieł wcześniejszych, nie tylko XVI-wiecznych, ale pochodzących jeszcze nawet z XIV stulecia. Zarazem jednak, do dzieła, które należałoby określić jako farmaceutyczne, Becher dodał uwagi i własne obserwacje alchemiczne. Dzięki temu Parnassus, chociaż jest późnym przykładem średniowiecznego traktatu medycznego, co dodatkowo podkreśla dołączenie do niego tłumaczenia Scholae salernitanae, stanowi jednocześnie wyraz popularnych około połowy XVII w. koncepcji alchemii, która od końca średniowiecza miała koncentrować się na badaniu substancji i ich możliwym zastosowaniu w medycynie. Związki między alchemią, farmacją i wczesnonowożytną chemią przejawiały się zatem między innymi w próbach ustalenia wpływu ciał niebieskich na właściwości chemiczne substancji wykorzystywanych w farmacji. Nakładające się obszary zainteresowań tych dziedzin sprawiły, że żywo interesujący się nimi Becher przygotował traktat łączący w sobie informacje o oddziaływaniu substancji organicznych i nieorganicznych na zdrowie człowieka.

Podstawowym elementem spajającym wszystkie części kompendium w spójną całość są jego ilustracje. Większość drzeworytów przygotowano w latach 1550 1560, zaś pozostałe opracowano sto lat później na podstawie różnorodnych źródeł, nadając im dość archaiczną formę i starając się upodobnić ich styl do przedstawień botanicznych, stanowiących podstawę korpusu ilustracyjnego traktatu. W niektórych przypadkach posłużono się najprawdopodobniej XVI-wiecznymi wzorcami.

Zasadnicza część drzeworytów pochodzi ze spuścizny po Joachimie Camerariusie. Kupione przez Johanna Görlina klocki kilkakrotnie inspirowały wydanie kompendiów przyrodniczych. Opracowane jeszcze za życia i pod nadzorem Konrada Gesnera, ilustracje były wykonane z natury i spełniały wszystkie wymagania, jakie w epoce nowożytnej stawiano ilustracji botanicznej. Wykonane ad vivum rysunki są sumaryczne i przedstawiają całą roślinę wraz z systemem korzeniowym, zwykle równocześnie w kilku fazach rozwoju - kwitnienia i owocowania. Proces przygotowania takich ilustracji wymagał kilkumiesięcznych studiów nad rośliną, by móc zaobserwować wszystkie zmiany zachodzące w trakcie cyklu wegetacyjnego. Tak skonwencjonalizowane przedstawienia botaniczne były powszechnie wykorzystywane przez przyrodników i farmaceutów, bowiem pozwalały na łatwe zapamiętanie

\footnotetext{
27 J. J. Becher, Parnassus medicinalis illustratus, Ulm 1662-1663, k. $\mathrm{a}_{\mathrm{iij}} \mathrm{r}$.
} 
wyglądu rośliny i jej szybką identyfikację ${ }^{28}$. W połowie XVII w. Gesner, o którym wiadomo, że sam przygotował wiele szkiców botanicznych ${ }^{29}$, był powszechnie cytowany jako dokładny i godny zaufania badacz. Jednakże pierwotne źródło tych klocków nie było w XVII w. znane i o ich renomie i wiarygodności świadczył autorytet innego przyrodnika - współczesnego Gesnerowi Joachima Camerariusa. Utrzymywali oni kontakty korespondencyjne i wymieniali się informacjami i eksponatami ${ }^{30}$, a po śmierci Gesnera Camerarius wykorzystał nieopublikowane ilustracje przyjaciela. W 1580 r. odkupił pozostawione przez Gesnera zbiory botaniczne od jego spadkobiercy, zuryskiego lekarza i przyrodnika Caspara Wolfa ${ }^{31}$. Kiedy w latach 80. XVI w. Camerarius przygotowywał do druku Kreutterbuch - niemieckie tłumaczenie zielnika Pietra Andrei Mattiolego, posiłkował się między innymi notatkami i ilustracjami - gotowymi klockami i szkicami przygotowawczymi, które szwajcarski uczony zebrał do opracowywanego przez siebie traktatu botanicznego. Zdobycie zbiorów Gesnera było dla Camerariusa dużym sukcesem a okoliczności tej transakcji opisał we wstępie do opublikowanego w 1586 r. Kreutterbuch ${ }^{32}$. Klocki przygotowane dla Gesnera zostały we Frankfurcie uzupełnione o dalsze drzeworyty wykonane z pozostawionych przez niego rysunków. Zbiór ten został opublikowany przez Camerariusa i pod jego nazwiskiem znany był wśród botaników i drukarzy XVI i XVII w. Jak wspominałam już wcześniej, pod koniec lat 50. XVII w. komplet klocków drzeworytniczych przygotowanych do Kreutterbuch kupił Johann Görlin Starszy. W Parnassusie wykorzystał pochodzące z tej kolekcji drzeworyty botaniczne [il. 9], a także przedstawienie cywety [il. 10] oraz umieszczone w ostatniej części Parnassusa ilustracje ukazujące aparaturę destylacyjną [il. 8].

Drzeworyty dwóch pozostałych ksiąg przygotowano ok. połowy XVII w. w ulmskiej drukarni Görlina specjalnie do tekstu opracowanego przez Bechera. Scena z Adamem i Ewą, większość przedstawień zwierząt oraz personifikacji minerałów sygnowane są monogramem MP [il. 11]. Umieszczony na tych drzeworytach podpis ma formę graficzną, którą posługiwało się kilku sztycharzy ${ }^{33}$, zatem identyfikacja ich autora może być jedynie prawdopodobna. Z dedykacji Bechera możemy wnioskować jedynie, że klocki te wykonane zostały w Ulm na zamówie-

${ }^{28}$ C. Swan, Lettura - Imago - Ostensio. The role of the 'Libri Picturari' A.18-A.30 in medical instruction at the Leiden University [w:] Natura - Cultura. L'interpretazione del mondo fisico nei testi e nelle immagini, red. G. Olmi et al., Firenze 2000, s. 209. Eadem, The uses of realism in Early Modern illustrated botany [w:] Visualizing Medieval Medicine and Natural History 1200-1550, red. J. Givens et al., Aldershot 2006, s. 245-247.

29 S. Kusukawa, The sources of Gessner's pictures for the Historia animalium, „Annals of Science" 67 (2010), s. 307.

30 Por. np. C. Delisle, op. cit.

31 F. Egmond, op. cit., s. 5.

32 P. A. Mattioli, op. cit., Frankfurt 1586, k. $)_{8}($.

33 Por. np. M. Bryan, Marks and monograms of early English and Continental engravers, London 1816; J. Heller, Monogrammen-Lexikon, Bamberg 1831, s. 274-275; G. K. Nagler, Die Monogrammisten und diejenigen bekannten und unbekannten Künstler, Bd. 4, München 1864. 
nie Görlina jako uzupełnienie do kupionych właśnie klocków Camerariusa. Jedyną próbę identyfikacji ich twórcy podjął w połowie XIX w. bawarski historyk sztuki Georg Kaspar Nagler. Według niego, monogramem w tej formie mógł posługiwać się Michael Philipp starszy, rysownik i sztycharz pracujący w Ulm, zapewne tożsamy z portrecistą działającym w latach 1650 . we Wrocławiu ${ }^{34}$. Sugestia ta budzi jednak pewne wątpliwości. W latach 1660-1690 w Ulm aktywny był także - znany głównie jako sztycharz - syn i imiennik Philippa starszego, który korzystał z identycznych graficznie monogramów, zaś przypisanie im poszczególnych dzieł nie jest jednoznaczne ${ }^{35}$.

Trzy drzeworyty zoologiczne sygnowane są monogramem MS [il. 12]. Wydaje się, że można z nim wiązać działającego w Ulm od ok. 1652 r. malarza i sztycharza Matthäusa Schultesa ${ }^{36}$. Stosunkowo najlepiej jest on znany z ilustracji do luterańskiej Biblii wydanej przez Christiana Lommera w $1671 \mathrm{r}$. Wykonane przez rytownika MS przedstawienia: lisa, borsuka i rysia są utrzymane w tym samym, archaizującym stylu, co drzeworyty sygnowane MP i ilustracje niesygnowane. Autorzy ilustracji najwyraźniej korzystali ze wspólnych źródeł. Ich identyfikacja jest dodatkowo utrudniona, bowiem przedstawienia zebrane w części zoologicznej Parnassusa nie stanowią oryginalnych drzeworytów zoologicznych. Są to kopie popularnych motywów ikonograficznych wykorzystywanych powszechnie w nowożytnej historii naturalnej. Rytownicy, którzy wykonali klocki z przedstawieniami zwierząt, na większość z nich przenieśli bez zmian ilustracje opublikowane dekadę wcześniej we frankfurckiej oficynie Merianów. W latach 1650-1653 ukazało się tam sześciotomowe dzieło Jana Jonstona Historiae naturalis libri ${ }^{37}$. Opracowane przez działającego w Lesznie medyka i przyrodnika kompendium było bogato ilustrowane miedziorytowymi przedstawieniami zwierząt. Zarówno tekst, jak i ilustracje tej encyklopedii przygotowano $\mathrm{w}$ oparciu o starszą literaturę z zakresu historii naturalnej ${ }^{38}$ oraz ryciny opracowywane przez najsłynniejszych artystów europejskich ${ }^{39}$. Miedzioryty z dzieła Jonstona zostały do traktatu Bechera uproszczone. Konieczność przeniesienia ich na klocki drzeworytnicze nie pozwoliła na zachowanie precyzyjnego rysun$\mathrm{ku}$, jaki miały miedzioryty wykonane $\mathrm{w}$ jednej $\mathrm{z}$ najlepszych frankfurckich oficyn połowy XVII w. [il. 13]. Mniej wprawne ręce, mechanicznie przenoszące ryciny na

${ }^{34}$ G. K. Nagler, op. cit., s. 650-651. Por. C. Nissen, Die zoologische Buchillustration, Bd. 1, Stuttgart 1969, poz. 273.

${ }^{35}$ G. K. Nagler, loc. cit.

${ }^{36}$ C. Nissen, loc. cit. O Schultesie zob. U. Thieme, F. Becker, Allgemeines Lexikon der bildenden Künstler, t. 30, Leipzig 1936, s. 326, tamże bibliografia.

37 J. Jonston, Historiae naturalis libri, Frankfurt 1650-1653. Na wykorzystanie tego źródła, a nie któregoś z wcześniejszych traktatów, wskazuje wybór kilku ilustracji niewątpliwie wzorowanych na rycinach z XVII w., jak np. przedstawienie słonia [il. 3].

${ }^{38}$ Najważniejszymi źródłami były kompendium M. Herra, Gründtlicher unterricht warhaffte und eigentliche Beschreibung [...] aller vierfüssigen thier, Strasburg 1546 oraz encyklopedia K. Gesnera.

${ }^{39}$ Zob. J. Czapla, Między autorem a drukarzem. Dobór ilustracji w "Historiae naturalis" Jana Jonstona [w:] Stowo i obraz w okresie staropolskim, („Zeszyty UJ. Nauki Społeczne”, nr 14), Kraków 2016 [przyjęty do druku]. 
klocki, dały też lustrzane odbicia ilustracji z warsztatu Merianów. Zebrane na tablicach miedziorytowych przedstawienia 29 ptaków, 30 stworzeń wodnych, płazów i węży, 21 owadów, pajęczaków (oraz salamandry i dwóch jaszczurek) ${ }^{40}$ wydają się być skopiowane z niezidentyfikowanej kompilacji niemieckiej [il. 4].

Brak, poza uproszczeniem rysunku, ingerencji w przedstawienia może sugerować, że zostały one wykonane przez młodych twórców, dla których było to jedno z pierwszych zleceń. Jest to jednak tylko hipoteza, której nie można potwierdzić bez rozległych badań archiwalnych wykraczających poza temat tego artykułu. Na tym etapie można jedynie stwierdzić, że wybrano do Parnassusa przedstawienia zwierząt dobrze znanych i często przedstawianych. Ilustracje kompendium Bechera ukazują gatunki zwykle opisywane w „Gärten der Gesundheit”. Są to wyłącznie rośliny i zwierzęta Starego Świata dobrze znane europejskim farmaceutom. Bogato ilustrowaną część botaniczną uzupełniono o skromniejsze, ale równie wiarygodne drzeworyty zoologiczne. Dzięki temu, Becher i Görlin uniknęli problemu, jaki stwarzać mogło opisywanie fauny egzotycznej, której wygląd nie zawsze był dobrze udokumentowany.

Odmienny charakter mają drzeworyty w trzeciej części Parnassusa. Mineralogia ilustrowana jest zbiorem alegorycznych przedstawień metali i związków nieorganicznych, z których część także jest sygnowana monogramem MP. Becher opracował tę księgę kompendium wyraźnie z perspektywy alchemicznej. Wybranym substancjom przypisywano silne związki z ciałami niebieskimi. Na drzeworytach przedstawiono bóstwa rzymskie i zwierzęta, które rządziły poszczególnymi metalami [il. 7]. Połączenie antro-, czy, w kilku przypadkach, zoomorfizacji substancji chemicznych z ich symbolami alchemicznymi pozwoliło na przedstawienie przypisywanych im magicznych właściwości - symbolizowanych przez związane z nimi bóstwa oraz na ich jednoznaczną identyfikację dzięki wykorzystaniu symboli stanowiących wspólny język alchemików.

W dołączonym do czwartej, nieilustrowanej, księgi krótkim poradniku o destylacji ukazano siedem naczyń laboratoryjnych, których ilustracje pierwotnie były zamieszczone w zielniku Camerariusa ${ }^{41}$. Określane jako „piece” różnego rodzaju alembiki i retorty miały zastosowanie praktyczne w produkcji leków. Przedstawienia sprzętów laboratoryjnych sumarycznie ukazują mechanizm ich działania [il. 8].

$\mathrm{Na}$ osobną uwagę zasługuje sztychowany przez ulmskiego twórcę, Jeremiasa Rennera miedziorytowy frontyspis [il. 14]. Przedstawiono na nim Apolla na tle pejzażu. Otoczony przez naczynia laboratoryjne bóg, trzymający lirę, stoi na wysepce na środku niewielkiej sadzawki. Wokół wysepki roją się różne gatunki zwierząt czworonożnych, ptaków, owadów, ryb i innych zwierząt wodnych. W oddali widać po prawej górską kopalnię i zadbany ogród w stylu francuskim, a po lewej urwiste zbocze, z którego spływa cienką strużką wodospad. Nad wodospadem zrywa się do lotu pegaz. W tle widoczne są pola uprawne i wzgórza. Frontyspis stanowi syn-

${ }^{40}$ Tej tablicy brak w egzemplarzu z Biblioteki Naukowej PAU i PAN w Krakowie.

${ }^{41}$ Zob. P. A. Mattioli, op. cit., k. 456v-459v. 
tetyczne ujęcie treści kompendium Bechera. Ukazano na nim zwierzęta, rośliny i minerały, które wykorzystywane były tak w farmacji, jak i w alchemii. Współżyją ze sobą, tworząc idylliczny Parnas, siedzibę muz i Apolla. Badaniom alchemicznym, a zapewne także wydaniu kompendium patronuje bóg, którego opiece powierzano nie tylko sztuki, ale też medycynę i nauki tajemne.

Ilustracje Parnassusa stanowią przykład stosunkowo rzadkiego zjawiska w publikacjach z zakresu historii naturalnej. W dziełach historycznych dobór ilustracji powszechnie pozostawiano decyzji drukarza, natomiast w przyrodniczych zwykle autor, jeśli nie decydował, to przynajmniej miał istotny wpływ na charakter ilustrujących je rycin ${ }^{42}$. Natomiast Parnassus został wydany z inicjatywy drukarza, który pragnął wykorzystać niedawno nabyte klocki drzeworytowe, odkupione ze zbiorów Camerariusa. To one stanowią podstawowy element reklamy dzieła. Zaakcentowano je w tytule, a w przedmowie opisano ich genezę. Zadanie zilustrowania ksiąg o zwierzętach i minerałach powierzono miejscowym, ulmskim sztycharzom, którzy oparli się na łatwo dostępnych źródłach drukowanych. Drzeworyty łączy spójny tekst, który Becher opracował w oparciu dawne kompendia farmaceutyczne, opisujące rośliny i zwierzęta, i uzupełnił o współczesne, siedemnastowieczne informacje o alchemicznych właściwościach metali i związków nieorganicznych. Wykorzystanie starszych, szesnastowiecznych rycin przyrodniczych stało się możliwe dzięki nadaniu im nowej interpretacji, ukazującej je z perspektywy alchemicznej i nowej oprawy włączającej je do zespołu ilustracji przedstawiającego Parnas, symboliczną siedzibę sztuk i nauk.

\section{JULIA CZAPLA}

\section{A $17^{\mathrm{TH}}$-CENTURY “GARDEN OF HEALTH”. PARNASSUS MEDICINALIS ILLUSTRATUS IN THE TRADITION OF ILLUSTRATED PHARMACEUTICAL COMPENDIUMS}

Summary

The article analyses a compendium Parnassus medicinalis illustratus published in the years 1662 1663. Prepared by Johann Joachim Becher, the work was a richly illustrated "garden of health" a collection of pieces of information on healing properties of plants, animals and minerals. An impulse to its publication was a purchase of woodcut blocks by a publisher, Johann Görlin the Elder. The blocks were made for Conrad Gesner and first printed in Pietro Andrea Mattioli's herbarium published by Joachim Camerarius the Younger in 1586. The prints were considered to have been well done and to be worth using again. They were supplemented with the prints patterned on the 16th-century treatises and prepared in Ulm. The history of the Parnassus woodcuts contributes into the research on the mechanisms of using old natural illustration. It is a rare example of a situation when a publisher came up with an initiative to publish woodcut blocks purchased from Camerarius's collection and supplemented them with new but old-like illustrations he commissioned and with a text inspired by the medival in form "gardens of health".

\footnotetext{
${ }^{42}$ Por. relacje między Jonstonem a Merianami analizowane w J. Czapla, op. cit.
} 